\title{
POLLEN OF NON-NECTARIFEROUS PLANTS IN THE MICROSCOPIC IMAGE OF HONYES OF SOME COMMUNES OF THE ŚWIĘTOKRZYSKIE VOIVODESHIP
}

\author{
Ernest Stawiarz \\ University of Life Sciences in Lublin, Department of Botany, Akademicka 15, 20-950 Lublin, Poland \\ e-mail: ernest.stawiarz@up.lublin.pl
}

Received: 3.09.2009

\begin{abstract}
In the investigated material, consisting of 143 honey samples, pollen grains of 109 taxa were identified; 80 were represented by nectariferous plants and 29 by non-nectariferous plants. In the pollen of nectariferous plants, 17 anemophilous and 12 entomophilous taxa were found. In particular honey samples, from 1 up to 13 taxa were noted. The identified pollen grains came from plants belonging to 19 botanical families. The most frequently represented families were as follows: Rosaceae, Poaceae and Ranunculaceae.

The percentage proportion of pollen of non-nectariferous taxa varied and it was within a range of $0.3 \%$ to $69.4 \%$.

The highest average frequency among anemophilous plants was demonstrated by the pollen of Poaceae (others), Quercus and Rumex, whereas among entomophilous plants by the pollen of Filipendula, Plantago and Fragaria.
\end{abstract}

Key words: pollen analysis, honey, non-nectariferous plants, Świętokrzyskie Voivodeship

\section{INTRODUCTION}

Among different components in honey, there are also floral pollen grains. Their presence is associated with contamination of nectar with pollen within a flower, secondary contamination of honey in combs or the blowing of pollen into a hive. In nectar honeys, entomophilous pollen is most frequently predominant, whereas honeydew honeys are often characterised by a high proportion of pollen of non-nectariferous (anemophilous and entomophilous) plants.

Melissopalynological analysis of a honey allows determining its botanical and geographical origin, the date of collection of the honey from the hive as well as distinguishing monofloral and multifloral honeys. Moreover, it enables plants providing pollen flow for bees to be identified.
The aim of the study was to identify the proportions of pollen of non-nectariferous (entomophilous and anemophilous) plants in honeys of some communes of the Świętokrzyskie Voivodeship (regional administrative unit). The study was conducted based on microscopic images of 143 honey samples.

\section{MATERIALS AND METHODS}

The object of the study was 143 honey samples collected in the years 2003-2005 from apiaries located within the Świętokrzyskie Voivodeship. During the successive apicultural seasons, 43, 51 and 49 samples were collected from 46 localities (17 different communes) in Opatów and Sandomierz Counties.

Microscopic pollen analysis was performed following the guidelines of the International Commission of Bee Botany (Louveaux et al. 1978) and the Polish Standard PN-88/A-77626 Bee Honey (1988), which complies with the recommendations of the International Honey Commission (von der O he et al. 2004). For each honey, glycerol-gelatine slides were prepared in two replicates.

The pollen spectrum was determined using a Nikon Eclipse E 600 light microscope at a magnification of $40 \times 15$. To this end, at least 300 pollen grains were counted in each slide, according to the recommendations of M o ar (1985). An attempt was made to assign these grains to a taxa as accurately as possible (species, genus, structure type or family) by using Zander's classification (1935, 1937). Unidentified pollen grains within a family were classified as "others"; for example, among Poaceae the following were identified: Zea mays, Cerealia and Poaceae (others). Nomenclature and systematic arrangement of plant taxa followed S z a f e r et al. (1967) and M i r e k et al. (1995). 
In order to determine pollen taxa as accurately as possible, comparative slides and available keys were used (Z a n d e r , 1935, 1937; H o d g e s , 1952; S a w yer, 1981, 1988; Ricciardelli d'Albore, 1998; B u c he r et al. 2004).

The pollen frequency for particular taxa of non-nectariferous (anemophilous and entomophilous) plants was determined based on the number of samples in which the presence of pollen of a given taxon was noted. It was calculated both for the whole material and for particular honey groups.

\section{RESULTS}

Based on the microscopic analysis results, 70 monofloral honeys and 73 multifloral honeys were distinguished in the examined material. Among the monofloral honeys, 35 turned out to be consistent with the Polish Standard. These were the following: 26 honeys from Brassica napus, 4 from Robinia pseudacacia, 3 from Tilia and 2 honeys from Fagopyrum. In addition, 35 honeys were determined as monofloral honeys not covered by this Standard. The following honeys were included in this group: 9 honeys from Trifolium (T. pratense and T. repens), 8 from Galeopsis, 7 from fruit trees (Prunus and Malus), 6 from Solidago, 2 from Phacelia and Sinapis alba as well as one honey from Salix.

In the 143 honey samples, pollen grains of 109 taxa were identified, among which 80 were represented by nectariferous plants and 29 by non-nectariferous plants. Among the pollen of non-nectariferous plants, 17 anemophilous and 12 entomophilous taxa were noted (Tab. 1). The presence of pollen of non-nectariferous plants was found in all the honeys. The number of their taxa in particular samples was within a range of 1 to 13 , which accounted for a proportion of $0.3-64.9 \%$ (Tab. 2). The identified taxa came from 19 botanical families: 15 from dicotyledons, 2 from monocotyledons and 2 from gymnosperms. The family Rosaceae was represented most frequently and pollen grains of Filipendula, Fragaria, Rosa and Sanguisorba were distinguished within this family. Among representatives of Poaceae, the pollen of Cerealia, Zea mays and Poaceae (others) was recorded, and among Ranunculaceae the pollen of Anemone, Hepatica and Ranunculus.

The pollen frequency of non-nectariferous plants in the honeys analysed varied in the study years (Fig. 1). The highest average frequency was demonstrated by the pollen of Poaceae (others) (80.4\%), Quercus (60.8\%) and Rumex (50.4\%) (Tab. 1). In the group with a frequency ranging between $30 \%$ and 50\%, Filipendula, Plantago, Fragaria, Papaver, Betula and Ranunculus were included. The pollen of
8 taxa had a lower frequency, within a range between $10 \%$ and $30 \%$. These were as follows: Artemisia, Anemone, Pinus, Chenopodiaceae, Zea mays, Hypericum, Cyperaceae and Cerealia. 12 other pollen taxa (7 anemophilous and 5 entomophilous) were also distinguished, the frequency of which did not exceed $10 \%$ (Tab. 1).

In spring honeys (rape and robinia) as well as in early summer honeys (lime and clover), Poaceae (others), Quercus and Pinus were predominant among the pollen of anemophilous taxa, whereas Fragaria, Papaver and Ranunculus predominated in the group of non-nectariferous entomophilous plants. In other honeys, in addition to Poaceae (others), numerous pollen grains of Artemisia, Chenopodiaceae and $\mathrm{Hy}$ pericum were noted. The highest variations in the frequency and proportion of pollen of non-nectariferous plants were found in multifloral honeys (Tabs 1,2). A comparison of pollen frequency of more important non-nectariferous plants in the study years is illustrated in Fig. 1. The highest range in the proportion of pollen of non-nectariferous plants was recorded in rape (0.3-50.0\%), lime (6.8-69.4\%) and multifloral honeys (0.9-54.5\%) (Tab. 2).

\section{DISCUSSION}

Pollen grains of non-nectariferous plants were present in all the honey samples analysed. The pollen of Poaceae (others), Quercus and Rumex had the highest frequency among anemophilous plants, whereas Filipendula, Plantago and Fragaria among nonnectariferous entomophilous plants. W a r a k o m s k a (1985) also found the presence of pollen grains of the abovementioned taxa in honeys originating from Jelenia Góra Valley. Their proportions in particular samples were assessed as subsidiary or dominant, however, this author found a lower frequency of Plantago and Fragaria pollen compared to honeys originating from the Świętokrzyskie Voivodeship. Pollen grains of Poaceae, Rumex, Plantago, Filipendula and Ranunculus were also characterised by a high frequency in honeys of the Podlasie region (W r ó b l e w s k a , 2002) and from north-eastern Poland (W róblew s k a et al. 2006). In analysing the pollen spectrum of some honeys from south-eastern Poland, C e g l i ńs k a and S t a w i a r z (2007) point out that Poaceae and Rumex reached the highest frequency in these honeys (58.4\%), whereas Artemisia had a lower frequency (45.8\%). Pollen grains of Poaceae (others), Quercus and Rumex were also characterised by a high frequency and proportion in the microscopic image of spring monofloral honeys from the Rzeszów area (C e g l i ń s k a , 2008).

Pollen of non-nectariferous plants is also noted in honeys coming from outside Poland. In Austrian hon- 


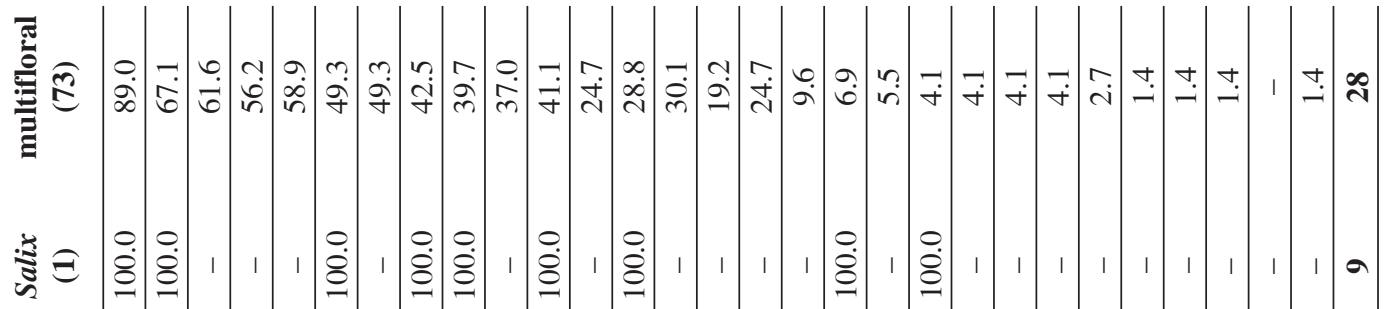

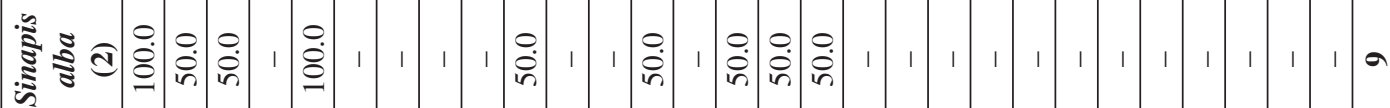
密

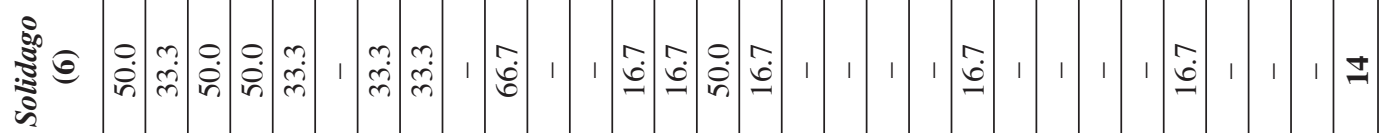

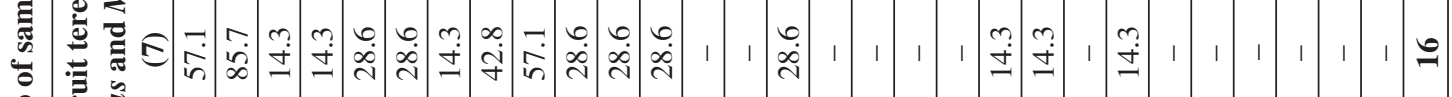

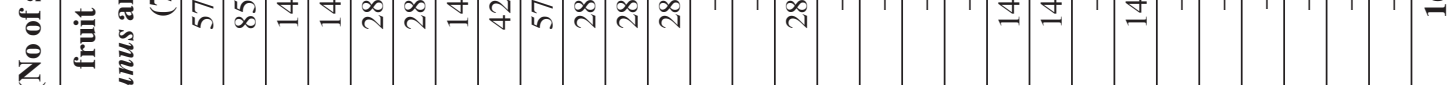
5

苟

竞

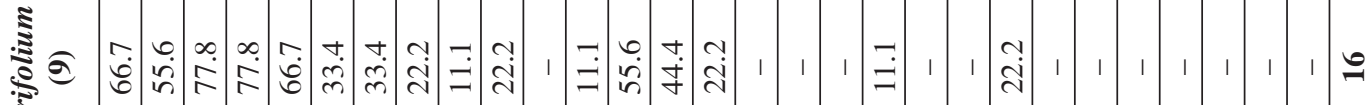
단

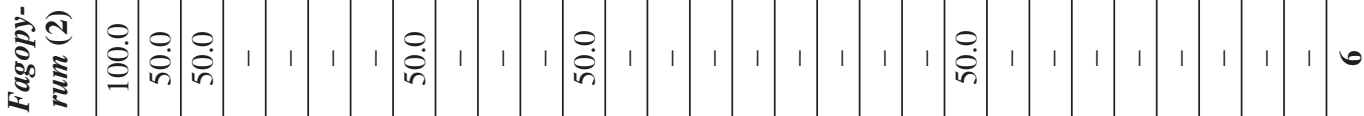

: ₹

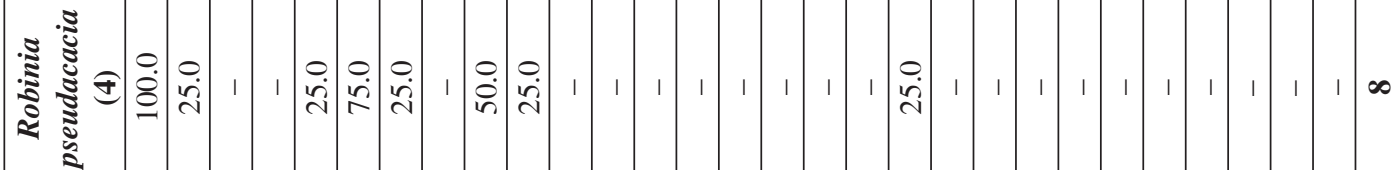

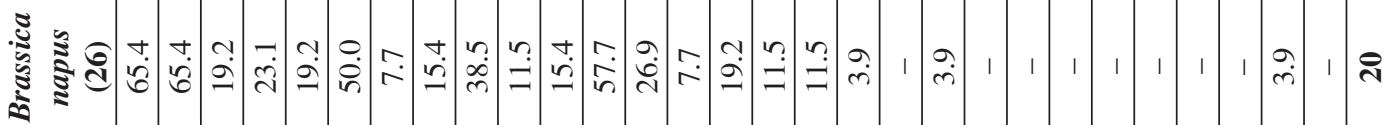

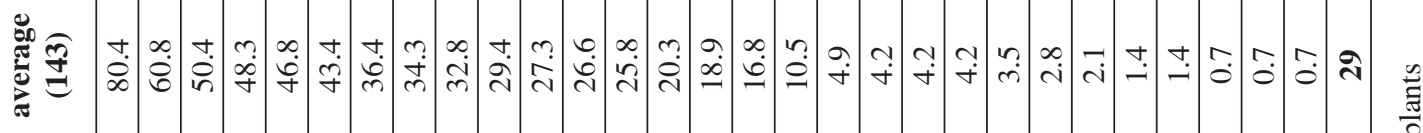

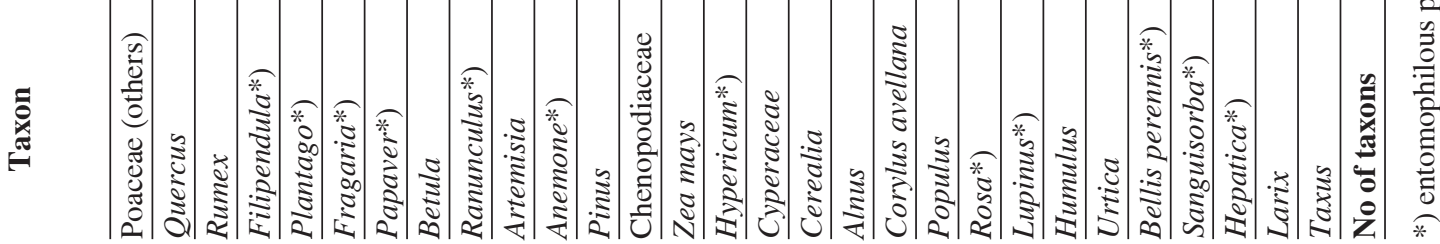


Table 2

Pollen percentage of non-nectariferous plants in the microscopic view in the examined honeys.

\begin{tabular}{|c|c|c|c|c|c|}
\hline \multirow{2}{*}{\multicolumn{2}{|c|}{ Sort of honeys }} & \multirow{2}{*}{$\begin{array}{c}\text { No of } \\
\text { samples }\end{array}$} & \multirow{2}{*}{$\begin{array}{l}\text { No of taxons } \\
\text { in one sample }\end{array}$} & \multicolumn{2}{|c|}{ Pollen percentage in samples $(\%)$} \\
\hline & & & & range & average \\
\hline \multirow{5}{*}{$\begin{array}{l}\text { Compatible with the } \\
\text { Polish Standard }\end{array}$} & Brassica napus & 26 & $1-12$ & $0.3-50.0$ & 5.6 \\
\hline & Robinia pseudacacia & 4 & $2-6$ & $0.5-9.4$ & 4.4 \\
\hline & Tilia & 3 & $5-9$ & $6.8-69.4$ & 34.0 \\
\hline & Fagopyrum & 2 & 2 and 5 & 1.8 and 6.1 & 3.9 \\
\hline & multifloral & 73 & $2-13$ & $0.9-54.5$ & 13.8 \\
\hline \multirow{7}{*}{$\begin{array}{l}\text { Not covered by the } \\
\text { Polish Standard }\end{array}$} & Trifolium & 9 & $2-10$ & $0.7-27.1$ & 12.8 \\
\hline & Galeopsis & 8 & $2-9$ & $0.6-10.2$ & 4.4 \\
\hline & $\begin{array}{l}\text { fruit trees } \\
\text { (Prunus and Malus) }\end{array}$ & 7 & $2-8$ & $0.5-17.7$ & 5.8 \\
\hline & Solidago & 6 & $2-8$ & $0.3-13.2$ & 5.1 \\
\hline & Phacelia & 2 & 4 and 6 & 3.7 and 7.6 & 5.6 \\
\hline & Sinapis alba & 2 & 5 and 6 & 2.7 and 3.8 & 3.2 \\
\hline & Salix & 1 & 9 & 4.8 & 4.8 \\
\hline
\end{tabular}

eys, W a r a k o m s k a and W o j t a c ki (1988) found the presence of pollen grains of Poaceae, which reached a frequency of $95 \%$, and Plantago with a frequency of $80 \%$. The abovementioned authors also frequently noted in honeys the presence of Quercus, Ranunculus and Rumex pollen. Poaceae pollen grains were also recorded in great numbers in Dutch (K e r k v li e t and Putten, 1975) and New Zealand honeys (M o a r, 1985). Moreover, in the latter Plantago and Rumex pollen grains were characterised by a high frequency. L a - S e rn a R a mos et al. (2000) recorded a $100 \%$ frequency of Rumex pollen in multifloral honeys from the Canary Islands, whereas Terrab et al. (2001, 2005) mention pollen grains of Poaceae, Quercus, Plantago and Fragaria among the most commonly found non-nectariferous taxa in honeys of Morocco. The pollen taxa mentioned by the said authors were also noted in fresh nectar samples collected from bees in Ireland (C offe y and B ree n, 1997). In Norwegian honeys, Filipendula (82\%) as well as the pollen of Hypericum and Rumex (50\%) were marked by the highest pollen frequency among non-nectariferous taxa (M a u ri zi o, 1979).

Pollen of different plant species is characterised by a variable proportion of nutrients, hence, a different nutritional value, and this determines its digestibility and usefulness as honey bee food (M a u r i z i o, 1954; Stawiarz, 2005). Maurizio (1954) mentions the pollen of nectariferous and non-nectariferous entomophilous plants among the most valuable pollen. He classifies the pollen of anemophilous plants in the group of medium and low-value pollen. However, these plants are particularly valuable in the spring period, when there is no other pollen flow for bees and the bee family develops intensively. The number of identified pollen taxa of non-nectariferous plants was much higher in honeys collected from hives in spring or early summer compared to honeys from a later period. It was undoubtedly associated with a larger number of nonnectariferous taxa flowering at that time. 


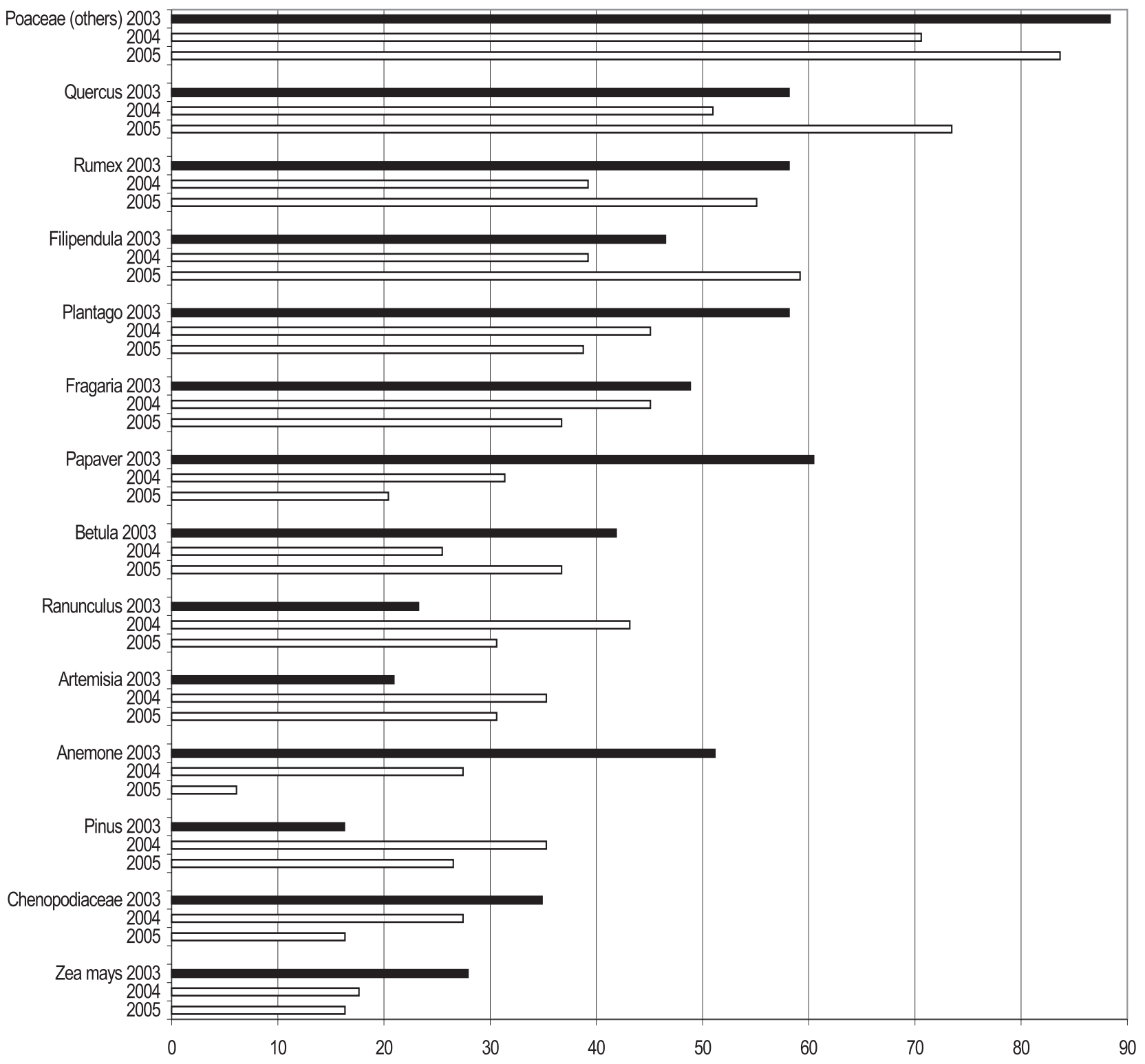

Fig. 1. Pollen frequency of the most important non-nectariferous plants in the examined honeys in 2003-2005 (\%).

\section{CONCLUSIONS}

1. In the investigated material, the presence of pollen grains of 17 anemophilous taxa and 12 non-nectariferous entomophilous taxa from 19 botanical families was noted.

2. The highest average frequency among non-nectariferous anemophilous taxa was demonstrated by the pollen of Poaceae (others), Quercus and
Rumex, whereas among non-nectariferous entomophilous taxa by the pollen of Filipendula, Plantago and Fragaria.

3. Spring and early summer honeys were characterised by a much higher proportion of pollen of nonnectariferous plants compared to honeys collected at a later period. 


\section{REFERENCES}

Bucher E., Kofler V., Vorwohl G., Zieger E., 2004. Das Pollenbild der Südtirolen Honige. Biologisches Labor der Landesagentur für Umwelt und Arbeitsschutz. Leifers.

Ceglińska K., 2008. Anemophilous plant pollen in spring specific honeys from the Rzeszów area. Acta Agrobot. 61 (1): 59-64.

C e gl i ń s k a K., S t a w i a r z E., 2007. Analiza mikroskopowa wybranych miodów z południowo-wschodniej Polski. / Pollen analysis of selected honeys of south-eastern Poland. Zesz. Nauk. Akademii Rolniczej im. H. Kołłątaja w Krakowie, 444 (93): 139-145.

Coffey M. F., Breen J., 1997. Seasonal variation in pollen and nectar sources of honey bees in Ireland. J. Apic. Res. 36 (2): 63-76.

Hodges D., 1952. The pollen loads of the honeybee, IBRA, London.

Kerkvliet J. D., Putten A. P. J., 1975. Das Pollenbild einiger niederlandischer Honide. Apidologie, 6 (3): 195206.

La-Serna Ramos I. E., Perez B. M., Ferreras C. G., 2000. Pollen characterization of multifloral honeys from La Palma (Canary Islands). Grana, 38 (6): 356-363.

Louveaux J., Maurizio A., Vorwohl G. 1978. Methods of Melissopalynology. Bee World, 59 (4): 139-157.

Maurizio A., 1954. Pollenernährung und Lebensvorgängen bei der Honigbiene (Apis mellifica L.). Landwirtsch. Jahrb. Schweiz. 68 (2): 115-182.

Maurizio A., 1979. Beitrag zur Kenntnis des Pollenspektrums norwegischer Honige. Apidologie, 10 (4): 359393.

Mirek Z., Piękoś-Mirkowa H., Zając A., Zając M., 1995. Vascular plants of Poland a checklist. Polish Academy of Sciences, W. Szafer Institute of Botany, Krakov.

Mo a r N. T., 1985. Pollen analysis of New Zealand honey. N. Z. J. Agric. Res. 28: 39-70.

Ohe von der W., Persano Oddo L., Piana M., Morlot M., M a r t in P., 2004 Harmonized methods of melissopalynology. Apidologie, 35: 18-25.

Polska Norma, Miód pszczeli. 1988. Wydanie Normalizacyjne, PN-88/A-77626. / Polish Standard, Bee honey. 1988. Edition Standards, PN-88/A-77626.

Ricciardelli d'Albore G., 1998. Mediterranean melissopalynology. Ed. Univ. degli studi di Perugia, Fac. di Agraria, Perugia.

S aw yer R., 1981. Pollen identification for beekeepers. Ed. R. S. Pickard, Univ. College Cardiff Press.

S aw yer R., 1988. Honey identification. Cardiff Acad. Press, Wales, UK.

Szafer W., Kulczyński S., Pawłowski B., 1967. Rośliny polskie. Państwowe Wydawnictwo Naukowe, Warszawa.
S t a w i a r z E., 2005. Znaczenie pyłku roślin wiatropylnych dla pszczół. / The importance of pollen of anemophilous plants for bees. Pszczelarstwo, 4: 12-13.

Terrab A., Castrillon B. V., Diez Dapana M. J., 2001. Pollen analysis of honeys from the Gharb Region (NW Marocco). Grana, 40 (4-5): 210-216.

Terrab A., Valdes B., Diez M. J., 2005. Study of plants visited by honeybees (Apis mellifera L.) in the Central Rif Region (N. Marocco) using pollen analysis. Grana, 44 (3): 209-215.

Warakomska Z., 1985. Obraz pyłkowy miodów i pierzgi Kotliny Jeleniogórskiej. / Pollen spectrum of honeys and bee bread of Jelenia Góra Valley. Pszczeln. Zesz. Nauk. 29: 253-263.

Warakomska Z., Wojtacki M., 1988. Obraz pyłkowy niektórych miodów Austriackich. / Pollen view of some honeys of Austria. Pszczeln. Zesz. Nauk. 32: 77-88.

Wróblewska A., 2002. Rośliny pożytkowe Podlasia w świetle analizy pyłkowej produktów pszczelich. / Flow flora of Podlasie in the light of pollen analysis of honeybee products. Wyd. AR w Lublinie, Zesz. 264: $1-83$.

Wróblewska A., Warakomska Z., Koter M., 2006. Pollen analysis of bee products from the north-eastern Poland. J. Apic. Sci. 50 (1): 71-83.

Zander E., 1935, 1937. Beiträge zur Herkunftsbestimmung bei Honig. I Reichsfachgrupp Imker, Berlin; II Liedloff, Loth \& Michaelis, Leipzig.

\section{Pyłek roślin nienektarodajnych w obrazie mikroskopowym miodów wybranych gmin województwa świętokrzyskiego}

\section{Streszczenie}

W badanym materiale, obejmującym 143 próbki miodów zidentyfikowano ziarna pyłku 109 taksonów, 80 reprezentowanych było przez rośliny nektarodajne, a 29 przez nienektarodajne. W obrębie pyłku roślin nienektarodajnych stwierdzono 17 taksonów wiatropylnych i 12 owadopylnych. W poszczególnych próbkach miodów notowano ich od 1 do 13. Określone ziarna pyłku pochodziły z roślin należących do 19 rodzin botanicznych. Najczęściej reprezentowanymi rodzinami były: Rosaceae, Poaceae i Ranunculaceae.

Udział pyłku taksonów nienektarodajnych był zróżnicowany i zawierał się $\mathrm{w}$ przedziale od $0.3 \%$ do $69.4 \%$.

Najwyższą średnią frekwencję wśród roślin wiatropylnych wykazał pyłek Poaceae (inne), Quercus i Rumex, wśród owadopylnych Filipendula, Plantago i Fragaria. 